\title{
WFDC2 wt Allele
}

National Cancer Institute

\section{Source}

National Cancer Institute. WFDC2 wt Allele. NCI Thesaurus. Code C51414.

Human WFDC2 wild-type allele is located within 20q12-q13.2 and is approximately $12 \mathrm{~kb}$ in length. This allele, which encodes WAP four-disulfide core domain protein 2 , is putatively involved in the innate immune response of the lung, nasal and oral epithelia. WFDC2 gene expression is up-regulated in certain cancers such as lung adenocarcinomas, pancreatic carcinomas and ovarian serous carcinomas. 